\title{
Demonstration of Pilot Scale Large Aperture Parabolic Trough Organic Rankine Cycle Solar Thermal Power Plant in Louisiana
}

\author{
Jonathan R. Raush ${ }^{1}$, Terrence L. Chambers ${ }^{1}$, Ben Russo ${ }^{2}$, Kenneth A. Ritter III ${ }^{1}$ \\ ${ }^{1}$ College of Engineering, University of Louisiana at Lafayette, Lafayette, USA; ${ }^{2}$ CLECO Power LLC, Pineville, USA. \\ Email: jrr1239@louisiana.edu
}

Received August 2013

\begin{abstract}
During the calendar year of 2012 the University of Louisiana at Lafayette in conjunction with CLECO Power LLC (CLECO) has constructed and commissioned a pilot scale parabolic trough solar thermal power plant for the first time in Louisiana. The large aperture trough (LAT) solar collectors were provided by Gossamer Space Frames and are coupled with an organic Rankine cycle (ORC) power block provided by ElectraTherm, Inc. for study of the feasibility of cost-effective commercial scale solar thermal power production in Louisiana. Supported by CLECO and providing power to the existing CLECO grid, the implementation of state-of-the-industry collector frames, mirrors, trackers, and ORC power block is studied under various local weather conditions which present varied operating regimes from existing solar thermal installations. The solar collectors provide a design output of $650 \mathrm{kWth}$ and preliminary actual performance data from the system level is presented. The optimal size, configuration and location for such a plant in the given solar resource region are being studied in conjunction with CLECO's search for optimal renewable energy solutions for the region. The pilot scale size of the facility and implementation of the simpler ORC allow remote operation of the facility and flexibility in operating parameters for optimization studies. The construction of the facility was supported by the Louisiana Department of Natural Resources, the U.S. Department of Energy, and CLECO. The continued operation of the plant is supported by CLECO Power LLC and the University of Louisiana at Lafayette.
\end{abstract}

Keywords: Concentrating Solar Power; Parabolic Trough; Solar Thermal; Organic Rankine Cycle; Power Plant

\section{Introduction}

The need for a diversified energy portfolio for stationary power generation is widely accepted, and solar energy is projected to provide a significant basis for this continued diversification during the coming decades [1]. While significant solar resource (greater than $6.0 \mathrm{kWh} / \mathrm{m}^{2} /$ day) exists in the southwest continental United States (US), much of the country is covered by a band of moderate solar resource $\left(4.0-6.0 \mathrm{kWh} / \mathrm{m}^{2} /\right.$ day $)$; it is in this band that the US state of Louisiana resides. Currently, concentrating solar power (CSP) offers the most economical commercial scale solar power option and there are many examples of existing or planned commercial scale installations in areas of high solar resource [2]. There are very few, however, commercial or pilot scale installations in areas of moderate solar resource and none in Louisiana [3]. The introduction of a pilot scale parabolic trough solar thermal power plant in Louisiana will allow the local demonstration of several key technical components of solar power as well as further the field as a whole with the development and validation of analytical models for further planning and innovation. A pilot scale facility would permit low-cost testing of various component technologies including concentrating solar collectors, thermal storage, and power blocks. In addition, flexibility in operational and testing configurations, including remote monitoring capabilities, would provide the opportunity for generating the necessary data for development and validation of full scale analytical models and feasibility studies for the region.

\section{Background}

\subsection{Project Development}

The investigation of CSP installations in areas of moderate solar resource is a need that has yet to be fully fulfilled. In addition, the development of distributed generation, small scale $(1-10 \mathrm{MW})$ solar installations offers several potential advantages including savings in transmission and distribution, improved reliability, and the potential to offset retail costs of electricity as opposed to 
wholesale [4]. On these scales, it has been suggested that coupling a CSP installation with an organic Rankine cycle (ORC) power block as opposed to a traditional Rankine cycle power block is an attractive option [5,6]. In 2011, the University of Louisiana at Lafayette was awarded a grant through the Louisiana Department of Natural Resources, originating from the US Department of Energy, to design, install, and commission a pilot scale solar thermal power plant. The construction and commissioning of the facility was completed during the 2012 calendar year.

\subsection{Solar Resource in Louisiana}

Louisiana resides in an area of the United States where the solar resource is substantially less than that of the current commercial scale CSP installations of the southwest US [3]. Figure 1 shows a map of the US Solar Resource developed by the National Renewable Energy Laboratory (NREL). Economical utilization of the solar resource in this region would significantly increase the footprint of viable areas for commercial development. Louisiana has an average solar resource between 4 and 5 $\mathrm{kWh} / \mathrm{m}^{2} /$ day. NREL Typical Meteorological Year (TMY3) data [7] resulted in a median peak direct normal irradi- ance (DNI) for the 6 months beginning in April of 688 $\mathrm{W} / \mathrm{m}^{2}$ for the Lafayette area, with a 15 percent error band. While these levels are substantially lower than those of the southwest US, the insolation still represents a significant level of energy. Indeed, based on the existing installed power capacity of Louisiana [8], one square mile of installed CSP projects would generate about one percent of the current capacity, based on a solar-to-electric efficiency of 20 percent.

\subsection{Project Goals}

The pilot solar thermal power plant was developed at the CLECO Alternative Energy Center in Crowley, Louisiana, and is operated by the University of Louisiana at Lafayette with the aim of installing and operating a pilot scale solar thermal facility for the first time in Louisiana. The overarching goal of the installation was to encourage the development, implementation and deployment of costeffective renewable energy technologies in Louisiana, to support the creation of additional employment opportunities, and to stimulate market demand for other emerging renewable energy systems. In addition, the research opportunities provided by the facility include the evaluation of the feasibility and commercial viability of full scale

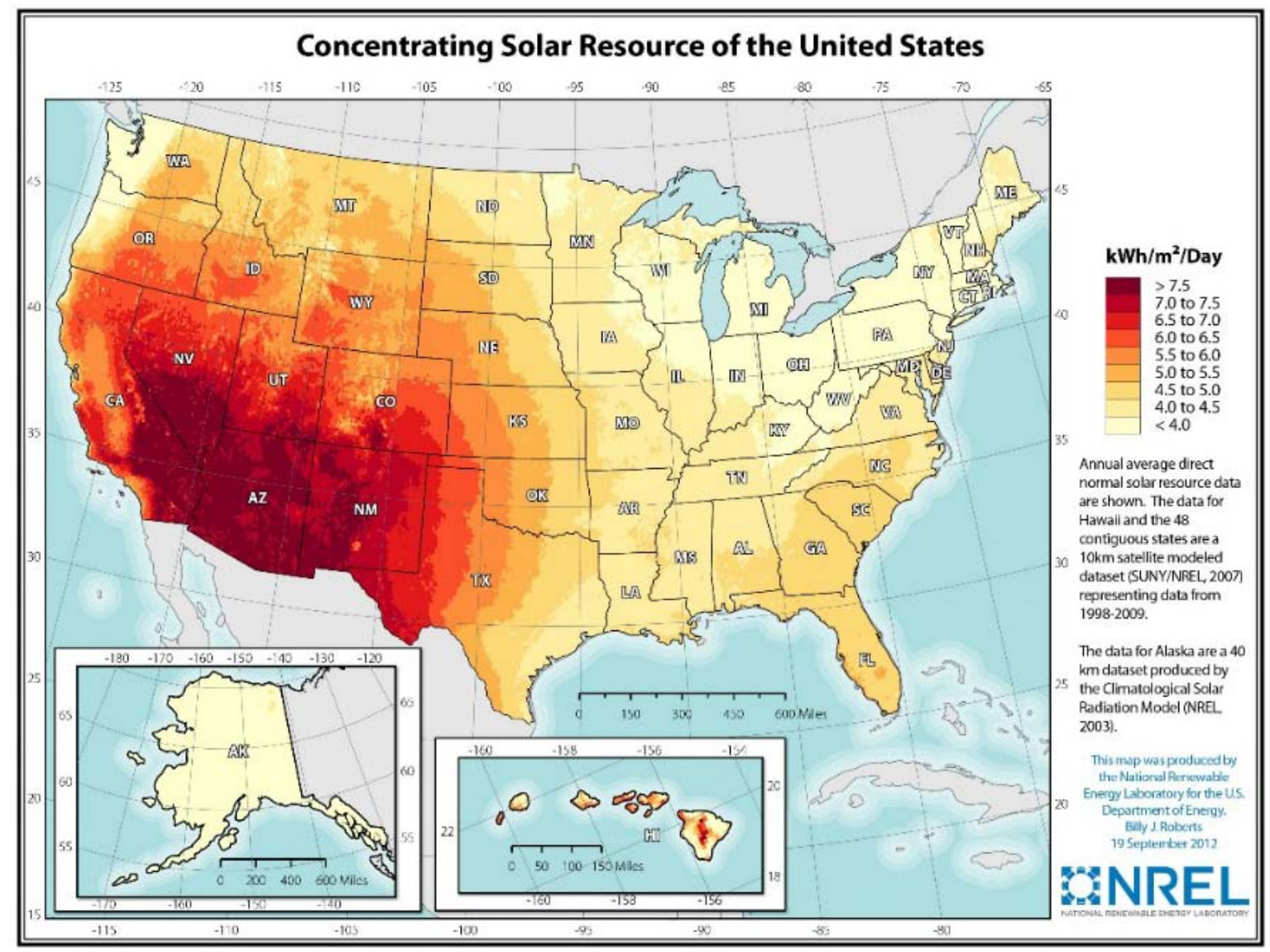

Figure 1. Concentrating solar resource of the US source: National renewable energy laboratory solar data center. 
solar thermal power plants in Louisiana, the study of distributed generation facilities for small and medium-sized municipalities, and to develop a laboratory where high fidelity analytical models could be created and validated. This project will also develop an accurate database of solar DNI values where to date the best available data is modelled from the NREL database.

\section{Plant Design}

\subsection{Design Objectives}

Several design objectives were identified in the development of the pilot scale parabolic trough power plant, while the major design constraints were issued by the grant program. The primary objective was that a parabolic trough solar collector field was to supply thermal energy to a power block for conversion to electricity. This electricity was to be supplied to an existing power grid. A secondary design objective was the inclusion of a thermal storage system to act as a thermal buffer for intermittent cloudy periods or when the solar irradiation exceeded design values. Installation of the thermal storage system had to be postponed, however, for budgetary reasons. The major constraints (in addition to the construction budget) were that all installed equipment were to be commercially available at the time of construction, and the net electricity production was to be limited to 20 $\mathrm{kW}$ net to the grid. Due to the limited output of the power plant, it was determined that an organic Rankine cycle (ORC) power block would be advantageous for several reasons, including simplicity, reliability, low maintenance, and remote monitoring [9]. This system would have the advantages of utilizing medium and low grade temperature thermal energy $\left(66^{\circ} \mathrm{C}-260^{\circ} \mathrm{C}\right.$ or $150-500$ ${ }^{\circ} \mathrm{F}$ ) and would operate at low pressures (less than 1380 $\mathrm{kPa}$ or $200 \mathrm{psig}$ ). Additional constraints included adherence to the "Buy America" provision of US Federal procurement policy. Due to the geographic proximity to the Gulf of Mexico, local design codes required a wind load rating of $169 \mathrm{~km} / \mathrm{h}$ (105 mph) for a three second gust for the installed solar collectors.

\subsection{Power Block Technology}

The selected ORC power block was the Green Machine series 4000 provided by ElectraTherm, Inc. The Green Machine was designed to accept low grade temperature water between 66 and $121^{\circ} \mathrm{C}\left(150^{\circ} \mathrm{F}\right.$ and $\left.250^{\circ} \mathrm{F}\right)$ as the thermal energy input and could produce up to $50 \mathrm{~kW}$ of electricity (kWe); although the newest models are capable of $65 \mathrm{kWe}$. The Green Machine is one of the few available ORC power blocks with power production capacity under $100 \mathrm{~kW}$, which also made it an attractive option for the facility.
The Green Machine utilizes R245fa as the organic working fluid in a Rankine cycle and can be either dry cooled or liquid cooled. For the current installation, due to the availability of municipal water service, an evaporative cooling tower was chosen as the cooling method. In the Green Machine working cycle, the working fluid is evaporated by heat exchange with the heat transfer fluid (HTF) and then expanded in a twin-screw expander. The twin-screw design provides low susceptibility to condensation and has low sensitivity to varying inlet conditions [5]. The expander is directly coupled to an electric generator producing 480 volts of AC power. Following expansion, the low pressure vapor is condensed by heat exchange with the cooling water and then accumulated before being pumped through a pre-heater and back into the evaporator. The hot water-to-refrigerant heat exchanger in the current model was designed for a hot water flow rate of 379 - $758 \mathrm{l} / \mathrm{min}$ (100 - $200 \mathrm{gpm})$. The overall thermal efficiency was expected to be about eight percent. This means that at design load, the ORC would need to be provided $650 \mathrm{~kW}$ of thermal power (kWth) in order to produce $50 \mathrm{kWe}$ power. Utilizing this figure and the minimum flow rate, $\dot{m}$ the desired temperature drop $(\Delta \mathrm{T})$ through the ORC could be calculated from the classic equation [10]:

$$
\dot{Q}=\dot{m} C_{p} \Delta T
$$

where $\dot{Q}$ is the energy flux and $C_{p}$ is the specific heat of the fluid. From this it was determined that a $28^{\circ} \mathrm{C}(50$ $\left.{ }^{\circ} \mathrm{F}\right) \Delta T$ through the ORC (and collector field) was required in order to provide the requisite $650 \mathrm{kWth}$ energy flux needed to produce the design capacity of $50 \mathrm{kWe}$.

\subsection{Solar Collector Technology}

The selected solar collector technology was the large aperture trough (LAT) parabolic trough solar collectors produced by Gossamer Space Frames (GSF). The GSF LAT, with an aperture of 7.3 meters, is the largest aperture trough currently available in commercial production. The current installation represents the second demonstration facility for the LAT. The collectors utilize an allaluminum space frame which provides high rigidity for improved accuracy while also minimizing weight. The collectors also satisfied the local building codes for wind load rating. The reflectors consisted of thin film polymer technology provided by $3 \mathrm{M}$ with silver as the reflective layer.

Schott PTR70 heat collection element (HCE) tubes with 70 millimeter outside diameter were employed which result in an industry leading concentration ratio (the ratio of the area of collected radiation to the area of concentrated radiation) of 104 . Due to the design of the ORC, water could be used as the HTF for the collector field. NREL laboratory testing of the GSF collectors demon- 
strated a slope error of less than 1.5 milliradian with over $99 \%$ intercept factor.

The LAT collector drives were designed for a single solar collector assembly (SCA) consisting of 16 collector frames, each 12 meters in length. For the current installation a loop was designed with 12 total collector frames; two SCAs of 6 frames each were employed due to space constraints. Additional key design parameters and metrics are listed in Table 1.

\section{Installation}

Construction of the facility began in June 2012 and was completed in December 2012. Approximately one acre of university property $\left(4050 \mathrm{~m}^{2}\right)$ was utilized. Ground preparation included leveling and grading with the collector field installed on cast concrete pylon foundations. Collector assembly and install were completed onsite with local labor resources used for nearly all of the skilled and unskilled work.

\section{Modeled Output}

Figure 2 shows the modeled output of the solar field per loop based on DNI, and the TMY3 dataset. For the design output of $650 \mathrm{kWth}$, a summer DNI of about 800 DNI would be expected to be required to maintain a constant output. Significant variability was expected due to seasonal weather conditions. Figure 3 uses the TMY3 dataset to model daily output over the course of one year. It should be noted the significant number of days forecasted with zero energy produced due to local weather conditions.

\section{Preliminary Performance Data}

In an effort to quantify the solar collector efficiency, a local hourly measurement of the DNI was required. Installation of a tracking pyreheliometer was completed in mid-July, 2013. DNI measurements from the first full

Table 1. Plant characteristics.

\begin{tabular}{cc}
\hline Plant Location & Crowley, LA \\
\hline Yearly Direct Normal Solar & $1590 \mathrm{kWh} / \mathrm{m}^{2}$ \\
Plant Size (nominal) & $50 \mathrm{kWe}$ \\
ORC Gross Output & $50 \mathrm{kWe}$ \\
Solar Field Heat Transfer Fluid & Water \\
Inlet Temperature & $93^{\circ} \mathrm{C}$ \\
Outlet Temperature & $121^{\circ} \mathrm{C}$ \\
ORC Working Fluid & $\mathrm{R} 245 \mathrm{fa}$ \\
ORC Design Point Efficiency & $8 \%$ \\
Solar Field Size & $1051 \mathrm{~m}{ }^{2}$ \\
Land Area & $4050 \mathrm{~m}^{2}(1 \mathrm{acre})$ \\
Solar to Electric Design Point Efficiency & $6 \%$ \\
\hline
\end{tabular}

kW Thermal Flow from Field vs. DNI

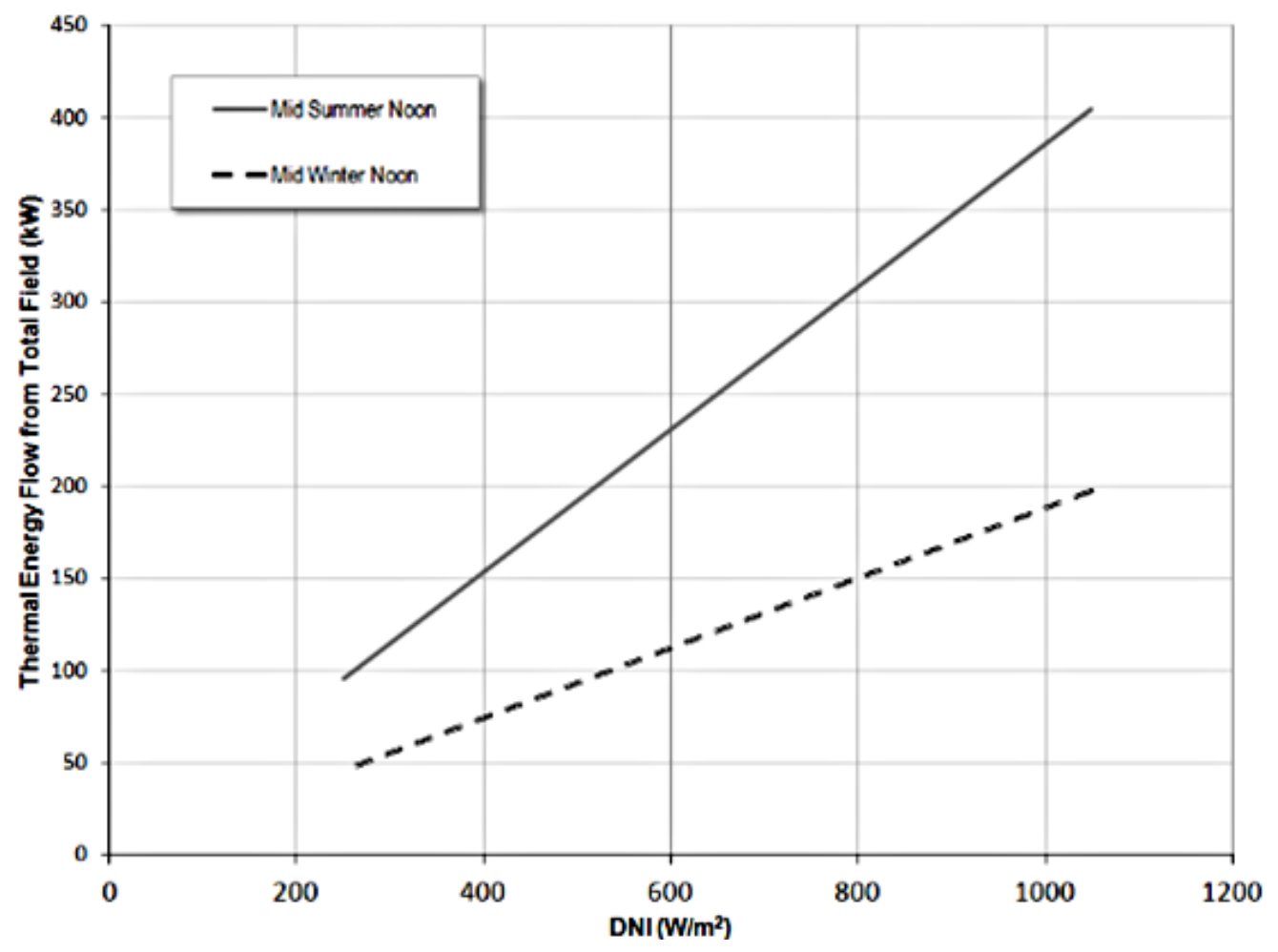

Figure 2. Collector field output vs. DNI. Source: 3 M. 


\section{Daily Total Energy Collected per Loop}

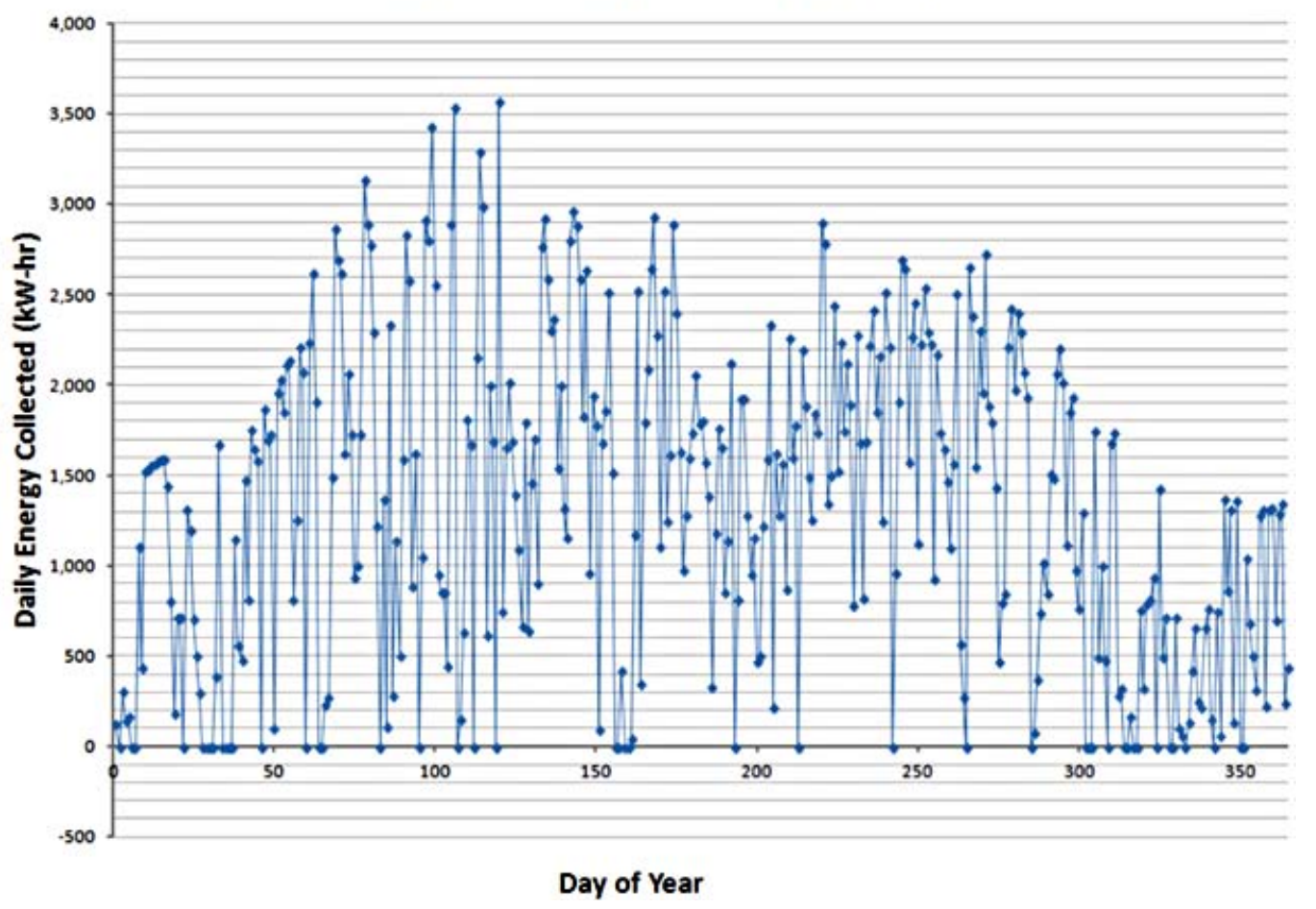

Figure 3. Modeled energy collected per day per loop. Source: 3 M.

month of installation resulted in an average daily peak of $771 \mathrm{~W} / \mathrm{m}^{2}$. This compares to the TMY3 data $652 \mathrm{~W} / \mathrm{m}^{2}$ for the same time period, or an 18 percent increase from the predicted value. Figure 4 shows the measured solar insolation in $\mathrm{kWh} / \mathrm{m}^{2} /$ day versus predicted data.

Due to the installation date, pyroheliometer data for the local area was not available for the first six months of operation of the sola collectors. During this period, the local global normal irradiance (GNI) was measured manually with a DBTU1300 Digital Solar Power Meter by General Tools which utilizes a silicone photovoltaic detector. In order to generate a DNI data point, a DNI/GNI ratio was employed. A review of the literature revealed this ratio could range anywhere from 0.5 to 0.8 [11]. Although more recent studies have shown the ratio to be above 0.8 , especially considering GNI values above 1000 $\mathrm{W} / \mathrm{m}^{2}$ [12]. Kurtz, Muller, Marion, and Emery found a ratio of 0.78 for GNI values between 975 and $1025 \mathrm{~W} / \mathrm{m}^{2}$ in a study of 30 different sites [12]. This range (975 to $1025 \mathrm{~W} / \mathrm{m}^{2}$ ) closely approximates the GNI values found for the days presented in this paper and thus the ratio of 0.78 was used to determine the DNI when direct measurement was not available.

Figure 5 gives the temperature distribution through the collector field vs. time for a typical day in April, 2013. Several peaks can be identified where one SCA was defocused in order to prevent temperatures in excess of the high temperature limit of the ORC. The apparent noise (rapid fluctuation) in the temperature measurements was possibly due to two phenomena. First, upon start-up, regions of fluid in the collector field were significantly hotter than fluid in the balance of plant and in the piping cross-over between SCAs. This is due to the secondary reflection of solar radiation onto the receiver tube even while not tracking. Without a thermal buffer in the system, there exists a period of time for the regions of higher temperature fluid to diffuse into the remaining areas, so that the temperature was uniform throughout the system. The second reason for temperature fluctuations was the continual balancing of the heat addition and heat removal of the ORC, again a result of a lack of thermal buffer in the system. The temperature distribution was found to be regular across the collector field as would be expected. Wind effects were found to be negligible.

Figure 6 presents the solar collector field energy output (flux) vs. time relative to the approximated DNI values. Figure 7 depicts solar collector field energy flux relative to measured DNI values for a day later in the summer. The fluctuation in temperature measurements also had the effect of creating noise in the calculated energy flux, which is a function of the temperature rise through the system. To offset this effect, the outlet temperature measurements of the collector field would need to be shifted in time, so that the inlet temperature measurement of a given fluid particle would correlated to its outlet temperature measurement, resulting in an accurate 
9

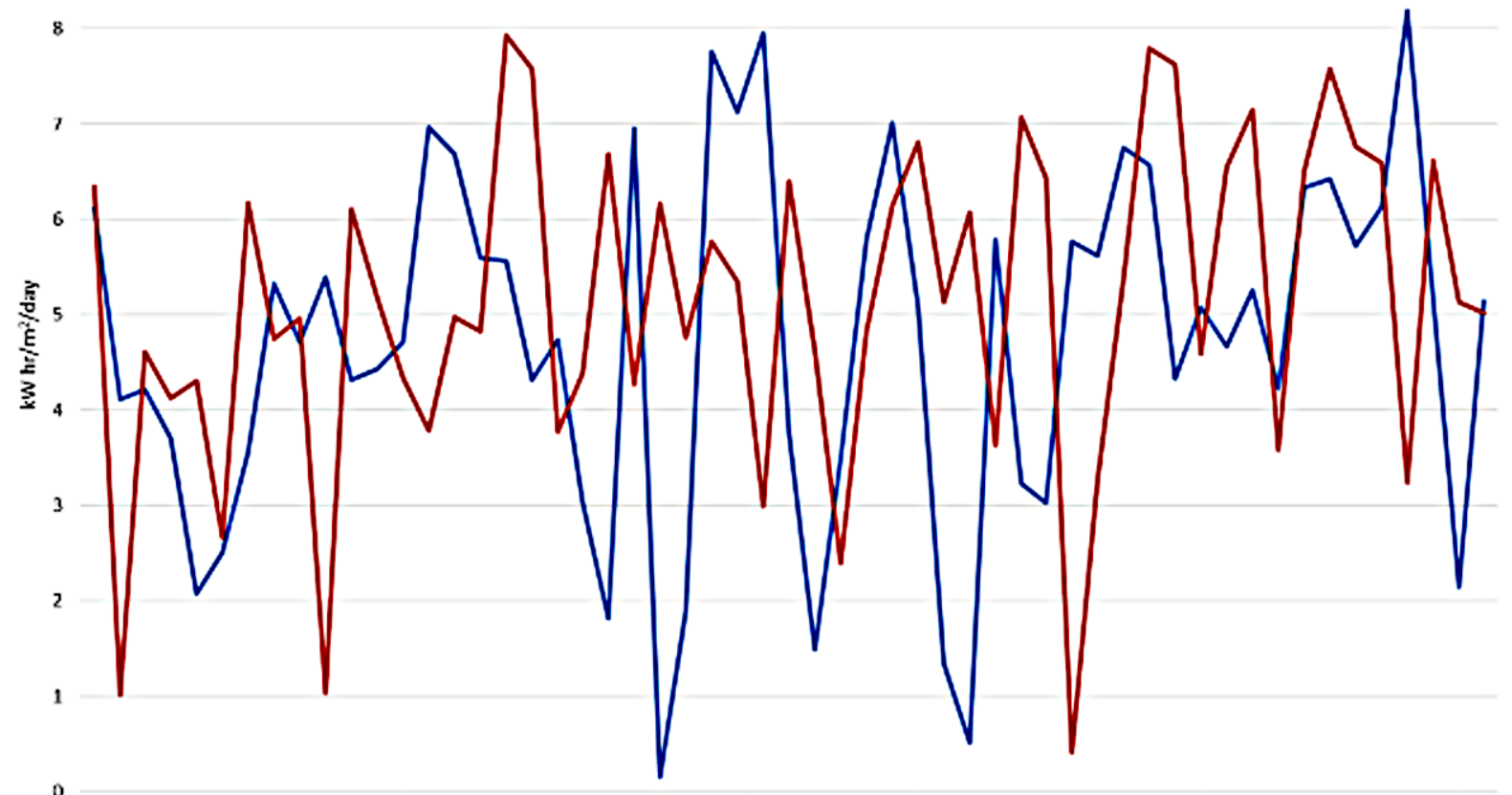

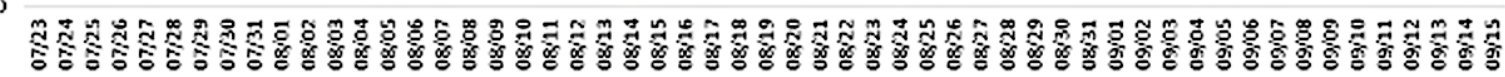

Axis Title

Figure 4. Measured solar insolation vs. actual.

Collector Field Temperature Distribution

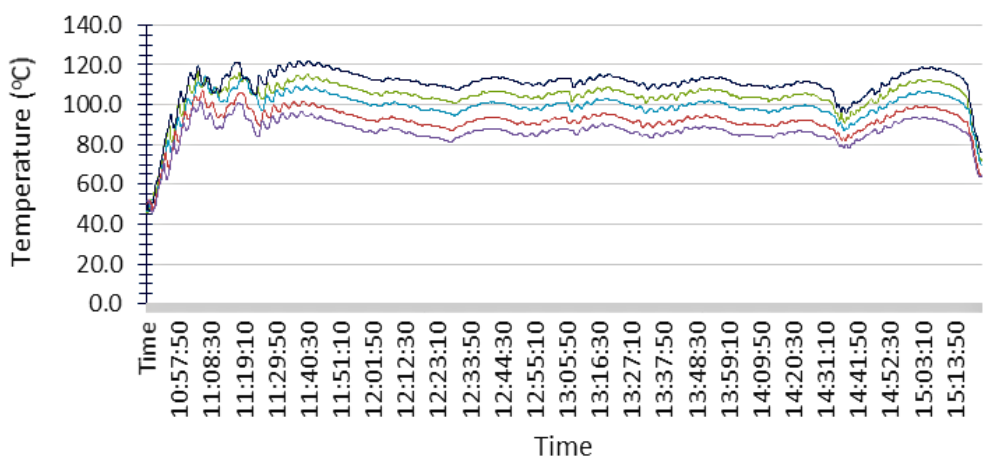

- East Drive Temp $\left({ }^{\circ} \mathrm{C}\right)-$ Xover Temp $\left({ }^{\circ} \mathrm{C}\right)$
West Drive Temp $\left({ }^{\circ} \mathrm{C}\right)-$ Inlet Temp $\left({ }^{\circ} \mathrm{C}\right)$

- Outlet Temp $\left({ }^{\circ} \mathrm{C}\right)$

Figure 5. Collector field temperature distribution.

$\Delta \mathrm{T}$ calculation. This adjustment has not been made to Figure 6 and so additional noise in the calculated energy flux is observed, yet was adjusted in Figure 7, where substantial fluctuations still exist, yet are dampened and dissipate more quickly for constant inlet conditions. An error band of five percent is displayed as a conserva tive estimate of the actual DNI and a linear trend line for the energy output is given for visualization in Figure 6. It can be seen that the design output of $650 \mathrm{kWth}$ was reached and maintained on this day with design solar irradiation. In contrast, the design output was not reached for the second day presented. Here, several degrading conditions are present that have not been quantified, including but not limited to the cosine effect of the sun 


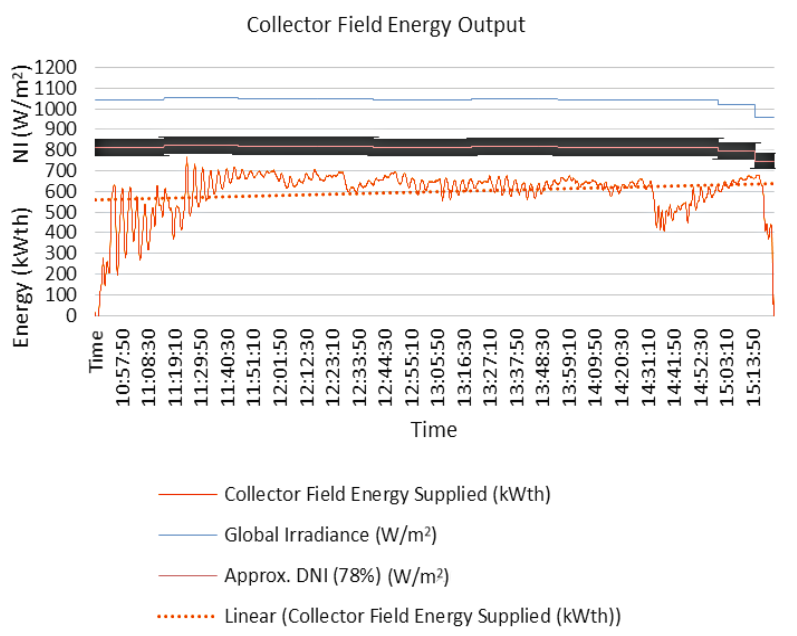

Figure 6. Collector field energy output. angle later in the year and the build-up of dirt from collector usage. The thermal efficiency of the collector field could then be evaluated by the given formula:

$$
n_{\mathrm{th}}=\frac{\dot{Q}}{(\text { Aperture Area }) *(\mathrm{DNI})}
$$

Here $\eta_{\text {th }}$ represents the thermal efficiency and $\dot{Q}$ is the thermal energy flux from the flow field. The efficiency of the solar field, based on the approximated DNI values, ranged between 70 and 80 percent (Figure 8), while the efficiency of the second day, based on measured DNI values, ranged between 65 and 75 percent (Figure 9). When considering the degrading factors mentioned earlier that have not been accounted for in the measurement, the efficiency values represent an industry standard, even after accounting for the low thermal losses which would

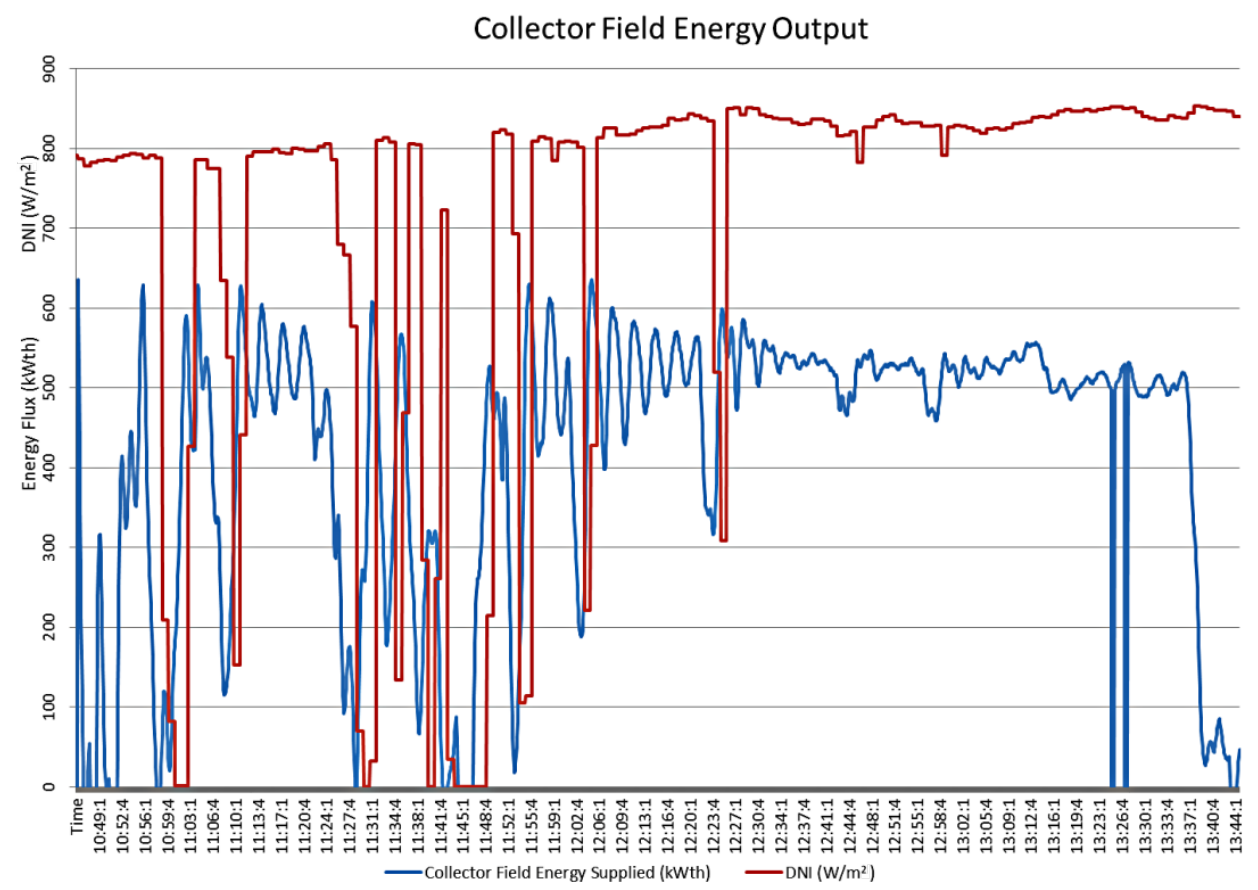

Figure 7. Collector field energy output, day 2.

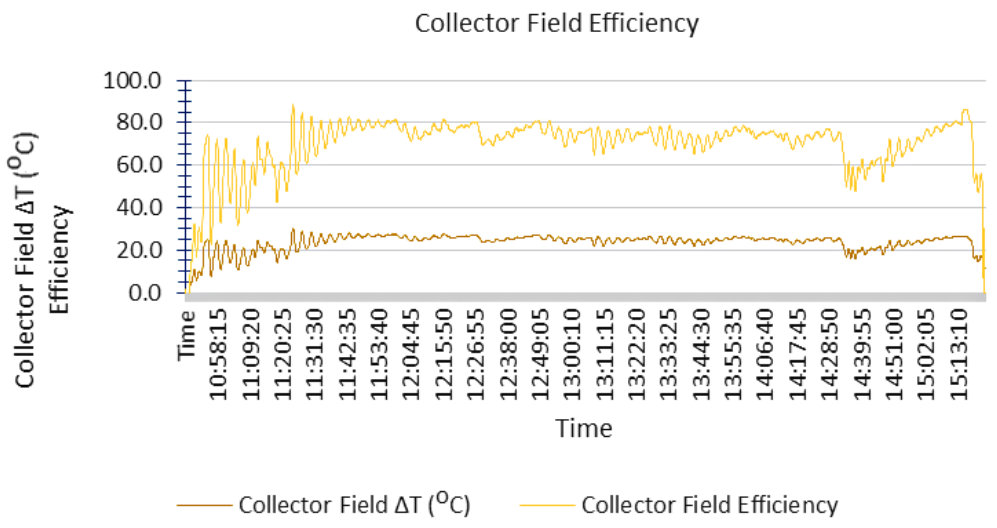

Figure 8. Collector field efficiency. 


\section{Collector Field Efficiency}

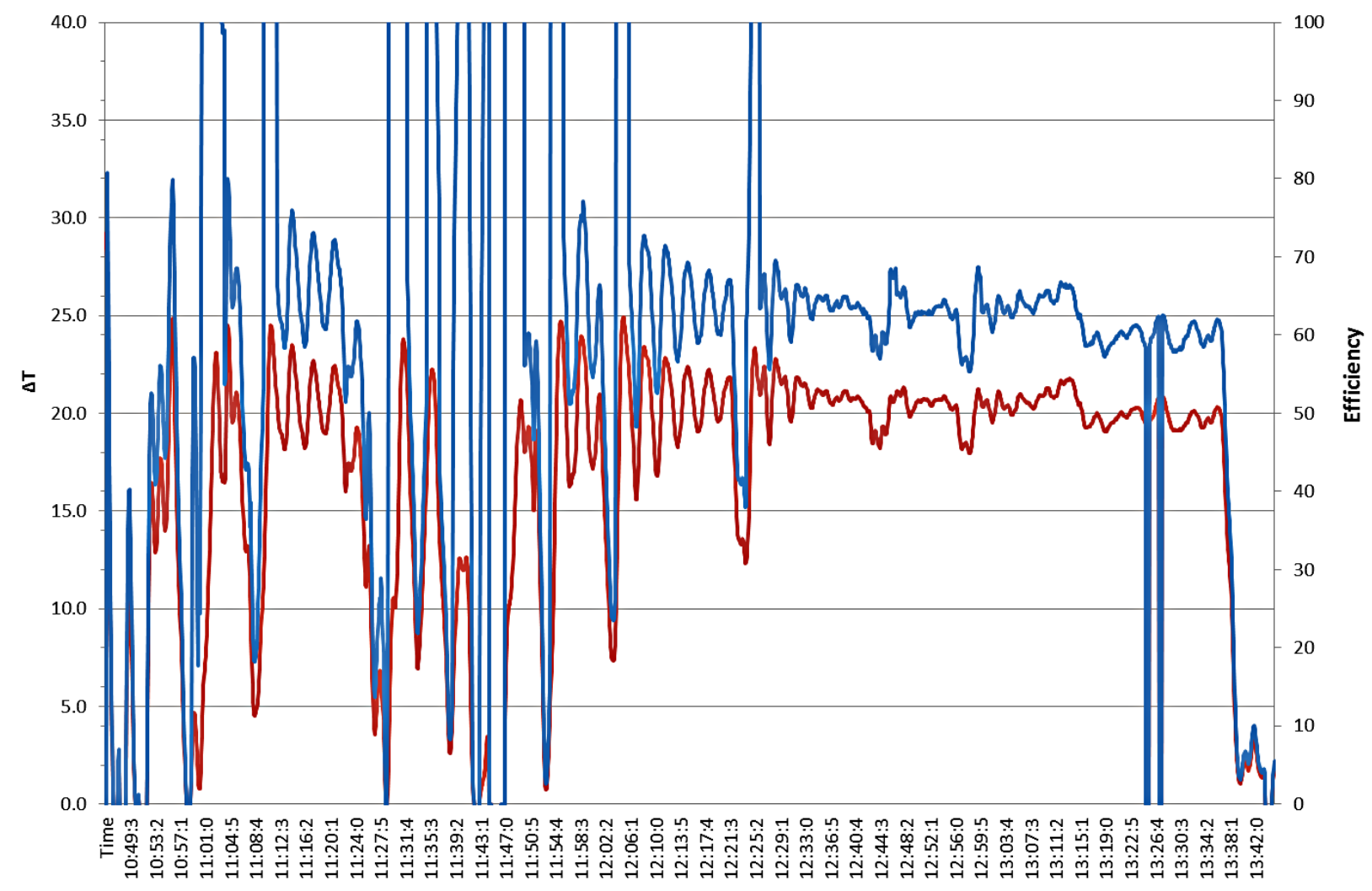

—Collector Field $\Delta \mathrm{T}(\mathrm{OC}) \quad$ Collector Field Efficiency

Figure 9. Collector field efficiency, day 2.

be expected due to the low temperature operating regime. Additionally, the cross-over piping between the two SCAs remain uninsulated, which is estimated to account for a one to two ${ }^{\circ} \mathrm{C}\left(2^{\circ} \mathrm{F}-4^{\circ} \mathrm{F}\right)$ temperature drop based on measured data, which would further increase overall thermal efficiency when insulated.

Figures 10 and $\mathbf{1 1}$ show the measured DNI for the second day presented, averaged by the minute and hourly, respectively, which highlights the variable conditions seen in the collector field data.

Figure 12 presents data depicting the ORC performance for the same day presented for the solar field in Figures 6 and 8 . The ORC power production is primarily a function of the temperature difference between the heat source and the cooling source. Depicted also is the power production in $\mathrm{kWe}$ relative to the $\Delta \mathrm{T}$ mentioned above. Figure 13 depicts the performance of the evaporative cooler. The low humidity and moderate temperatures result in effective cooling relative to the ambient temperature. Finally, the thermal efficiency of the ORC was determined by simply calculating the ratio of electric power produced to thermal power supplied. Figure 14 presents the thermal efficiency of the ORC, which was between 7 and 8 percent, within the design conditions.
Also shown is the theoretical Carnot efficiency for the cycle and 75 percent of the Carnot efficiency, which is commonly considered the engineering limit.

\section{Results and Future Work}

The University of Louisiana at Lafayette, in conjunction with CLECO Power LLC, has installed and commissioned a pilot scale solar thermal power plant in Louisiana for the first time. Following commission in December, 2012, testing and operation of the facility commenced. Initial preliminary performance data has been presented which demonstrates that the collector field and ORC power block are operating at or near the design point on an efficiency and power output basis. In the case of the collector field, initial performance has in some cases exceeded expected values. Improvements to the performance will be expected when additional work is completed including adding insulation to exposed piping at the crossover between SCAs (15 linear meters) and a regime for cleaning the mirrors is introduced. Regarding the ORC, the initial performance at or near design point is highlighted by the fact that the input flow rate of the ORC requires a minimum of $379 \mathrm{l} / \mathrm{min}$ while the current HTF 


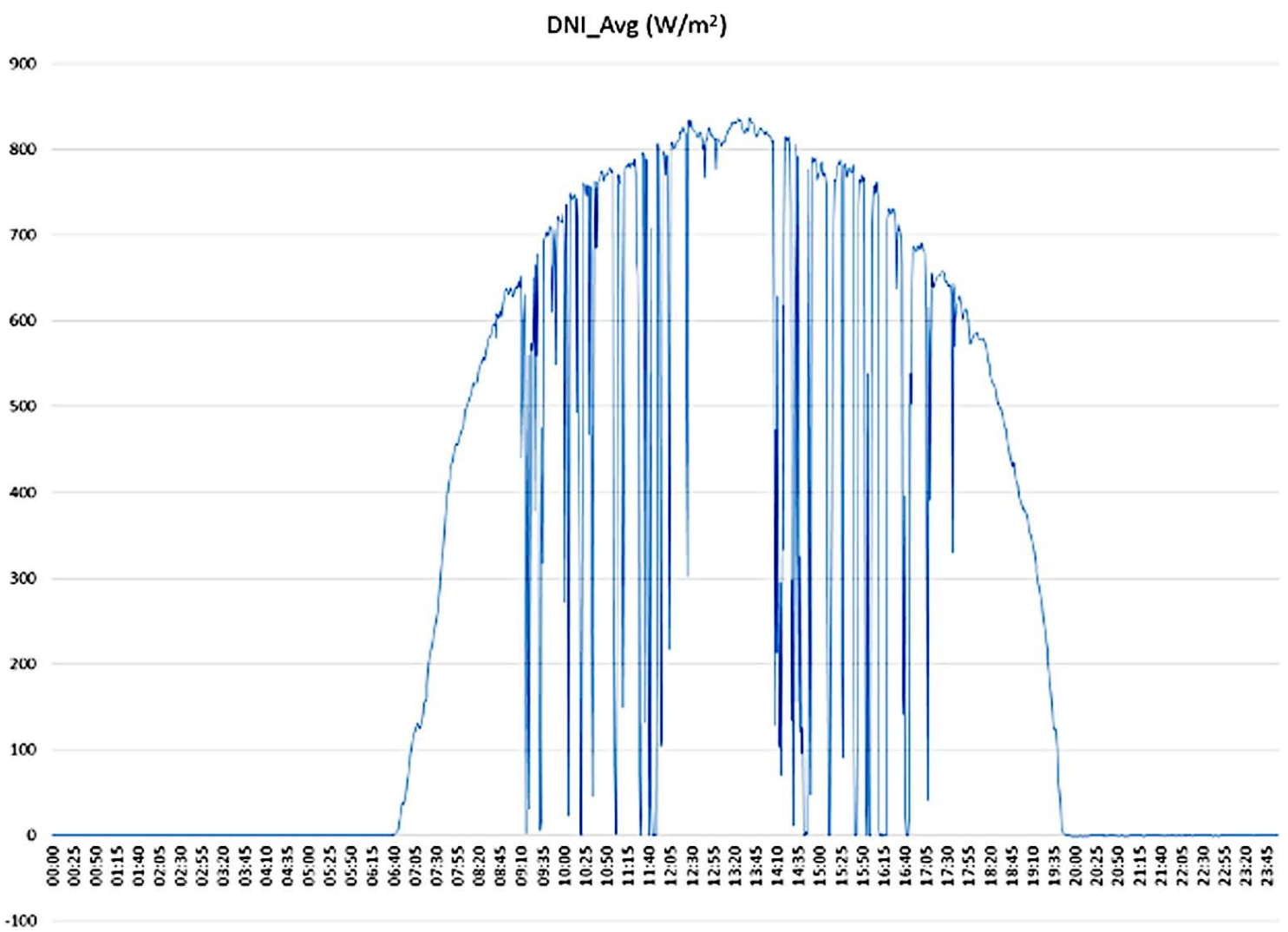

Figure 10. Measured DNI for day 2, averaged by minute.

DNI Avg (W/m²)

900

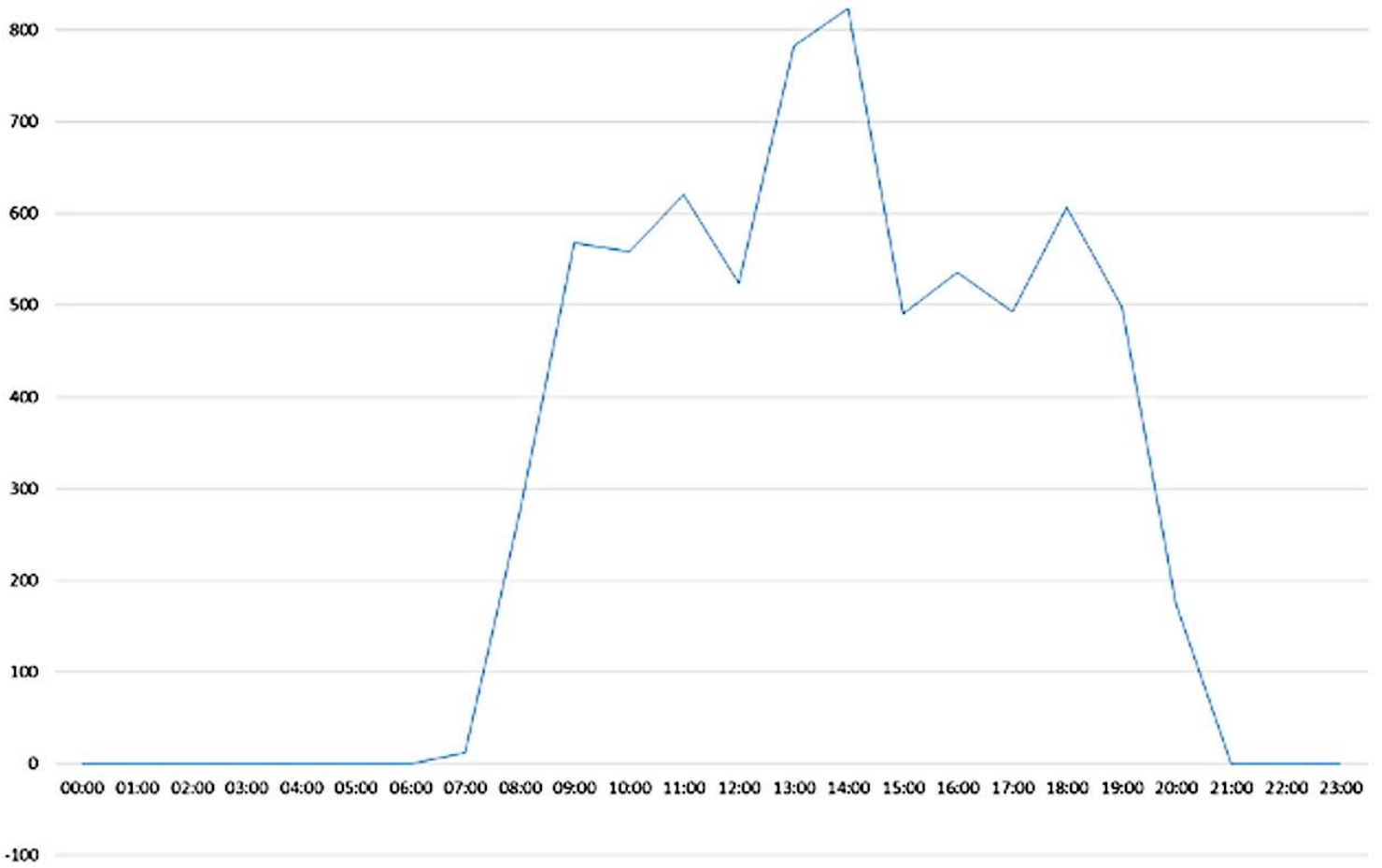

Figure 11. Measured DNI for day 2, averaged hourly. 


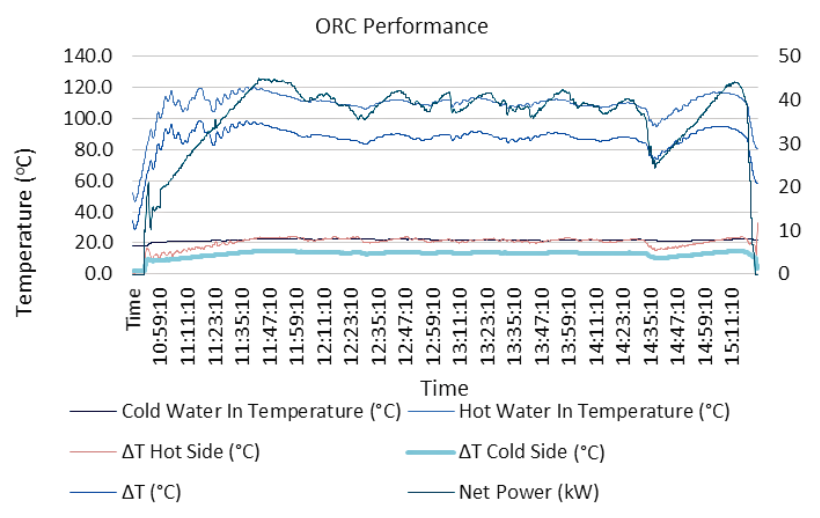

Figure 12. ORC performance data.

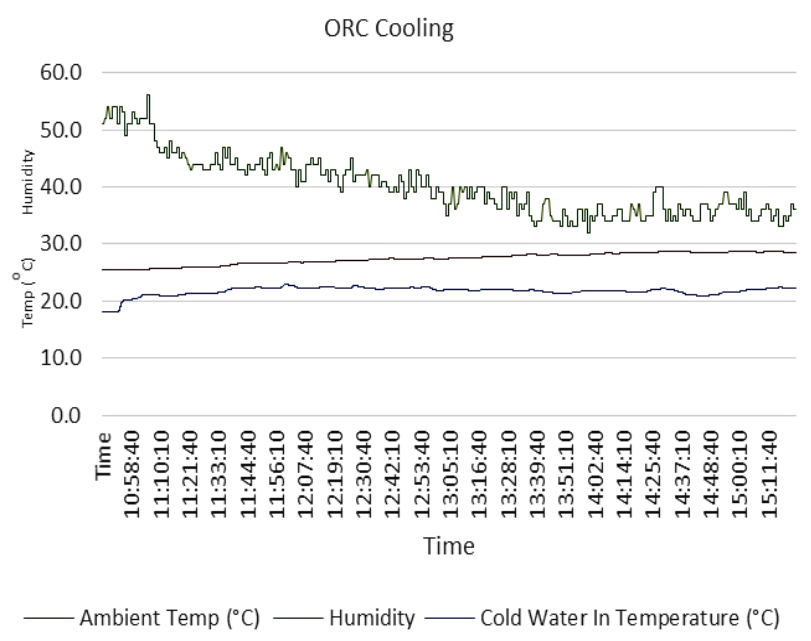

Figure 13. ORC cooling data.

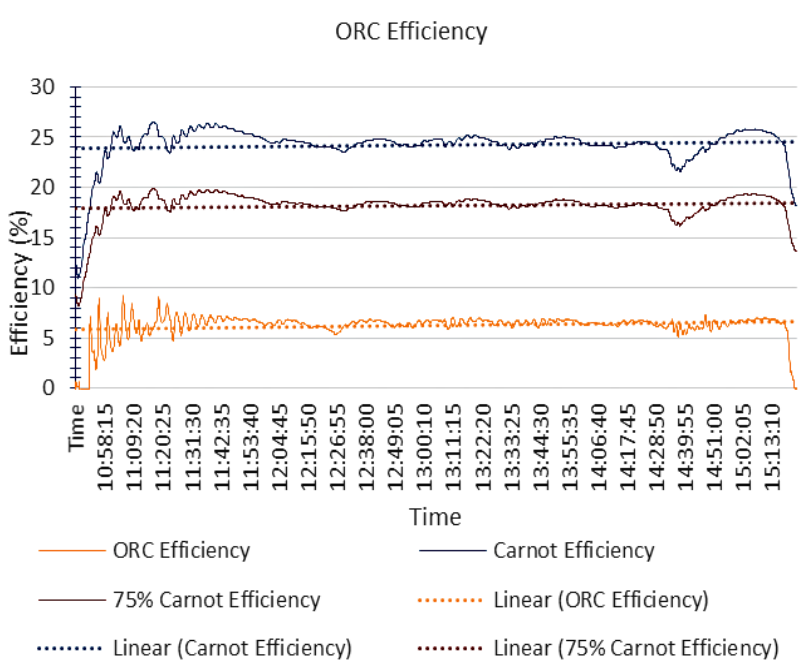

Figure 14. ORC efficiency.

flow rate is at a maximum at this value. Future work will include adding variable frequency drives to the HTF pump to modulate and optimize the HTF flow rate for improved ORC heat removal. Losses in the system must be quantified for optimization, including quantifying the level of degradation in specularity due to dirt build-up on the mirrors. Pumping losses for the HTF and the evaporative cooler totaled about $3.5 \mathrm{kWe}$.

In addition, the current data represents operation in moderate ambient temperatures and low humidity, leading to effective evaporative cooling. The summer months of the local area will bring higher humidity and ambient temperatures which will adversely affect cooling and overall thermal efficiency. Considerable fluctuations in the thermal output of the collector field were due to a lack of thermal buffer. Future work calls for the installation of a thermal storage/buffer system which will act to remove the high levels of variability due to cloudy conditions and collector field-ORC balancing acting to further optimize the system. Additional work will also include the continued collection and study of measured DNI data, which will serve to improve efficiency calculations, create a database for local conditions which will replace TMY3 data in analytical models, and inform local DNI/GNI ratios.

\section{Acknowledgements}

This work was funded by a grant from the Louisiana Department of Natural Resources under the EmPower Louisiana Renewable Energy Grant Program, award number RE-06, the United States Department of Energy through the American Recovery and Reinvestment Act of 2009 and CLECO Power LLC.

\section{REFERENCES}

[1] John Conti, et al., “Annual Energy Outlook 2013,” US Energy Information Administration, 2013. www.eia.gov/forecasts/aeo

[2] T. Chambers, J. Raush and G. H. Massiha, "Pilot Solar Thermal Power Plant Station in Southwest Louisiana," International Journal of Applied Power Engineering, Vol. 2, No. 1, 2013, pp. 31-40.

[3] US National Renewable Energy Laboroatory, "Concentrating Solar Power Pojects in the United States." http://www.nrel.gov/csp/solarpaces/by_country_detail.cf $\mathrm{m} /$ country=US\%20\%28\%22_self\%22\%29

[4] H. Price and V. Hassani, "Modular Trough Power Plant Cycle and Systems Analysis,” US National Renewable Energy Laboratory, 2011. www.nrel.gov/csp/troughnet/pubs_power_plant.html

[5] S. Quoilin, M. Orosz, H. Hemond and V. Lemort, "Performance and Design Optimization of a Low-Cost Solar Organic Rankine Cycle for Remote Power Generation,” Solar Energy, Vol. 85, 2011, pp. 955-966. http://dx.doi.org/10.1016/j.solener.2011.02.010

[6] A. McMahan, "Design and Optimization of Organic Rankine Cycle Solar Thermal Powerplants,” M.S. Thesis, University of Wisconsin, Madison, 2006.

[7] S. Wilcox, "National Solar Radiation Databse 1991-2010 
Update: User’s Manual,” US National Renewable Energy Laboratory, 2013.

http://www.nrel.gov/docs/fy12osti/54824.pdf

[8] US Energy Information Administration, "State Electricity Profiles 2010,” 2013. http://www.eia.gov/electricity/state/pdf/sep2010.pdf

[9] S. Canada, G. Cohen, R. Cable, D. Brosseau and H. Price, "Parabolic Trough Organic Rankine Cycle Solar Power Plant,” DOE Solar Energy Technologies Program Review Meeting, 2004.

[10] Y. Çengel and M. Boles, “Thermodynamics an Engi- neering Approach,” 7th Edition, McGraw-Hill, New York, 2011.

[11] A. Antonini, "Photovoltaic Concentrators-Fundamentals, Applications, Market \& Prospective.” In: R. Manyala, Ed., Solar Collectors and Panels, Theory and Applications, Sciyo, 2010. pp. 31-54. http://dx.doi.org/10.5772/10330

[12] S. Kurtz, M. Muller, B. Marion and K. Emery, "Considerations for How to Rate CPV," 6th International Conference on Concentrating Photovoltaic Systems, 2010. 